Article

\title{
Impact of Encouraging Vehicles to Refuel at Night on Ozone and Non-Methane Hydrocarbons (NMHCs): A Case Study in Ji'nan, China
}

\author{
Wenxuan Chai ${ }^{1}$, Yaolong Shi ${ }^{1}$, Kun Hu ${ }^{2}$, Yujing Hou ${ }^{1}$, Siyuan Liang ${ }^{1}$, Wentai Chen ${ }^{3}$, Ming Wang ${ }^{2, *}$ \\ and Guigang Tang ${ }^{1, *}$
}

Citation: Chai, W.; Shi, Y.; Hu, K.; Hou, Y.; Liang, S.; Chen, W.; Wang, M.; Tang, G. Impact of Encouraging Vehicles to Refuel at Night on Ozone and Non-Methane Hydrocarbons (NMHCs): A Case Study in Ji'nan, China. Atmosphere 2021, 12, 555. https://doi.org/10.3390/ atmos12050555

Academic Editors: Yun Zhu, Jim Kelly, Jun Zhao, Jia Xing and Yuqiang Zhang

Received: 30 March 2021

Accepted: 23 April 2021

Published: 26 April 2021

Publisher's Note: MDPI stays neutral with regard to jurisdictional claims in published maps and institutional affiliations.

Copyright: (c) 2021 by the authors. Licensee MDPI, Basel, Switzerland. This article is an open access article distributed under the terms and conditions of the Creative Commons Attribution (CC BY) license (https:/ / creativecommons.org/licenses/by/ $4.0 /)$.
1 China National Environmental Monitoring Centre, Beijing 100012, China; chaiwx@cnemc.cn (W.C.); shiyl@cnemc.cn (Y.S.); houyj@cnemc.cn (Y.H.); liangsy@cnemc.cn (S.L.)

2 Collaborative Innovation Center of Atmospheric Environment and Equipment Technology, Jiangsu Key Laboratory of Atmospheric Environment Monitoring and Pollution Control, School of Environmental Science and Engineering, Nanjing University of Information Science \& Technology, Nanjing 210044, China; hukun@nuist.edu.cn

3 Nanjing Intelligent Environmental Science and Technology Co., Ltd., Nanjing 211800, China; chenwentai@ies-tech.cn

* Correspondence: wangming@nuist.edu.cn (M.W.); tanggg@cnemc.cn (G.T.)

\begin{abstract}
Gasoline evaporation is a potential source of ambient non-methane hydrocarbons (NMHCs) during summer, and thus the policy of encouraging vehicles to refuel at night has been implemented to control ground-level ozone $\left(\mathrm{O}_{3}\right)$ and NMHCs. In this study, NMHCs and trace gases were observed online at an urban site of Ji'nan during May-July in 2019 and 2020 to assess the impact of this policy. After the implementation of this policy, the average concentration of daily maximum $8 \mathrm{~h}$ moving average $\mathrm{O}_{3}$ decreased from $198 \mu \mathrm{g} / \mathrm{m}^{3}$ to $181 \mu \mathrm{g} / \mathrm{m}^{3}$. Meanwhile, the average mixing ratio of NMHCs decreased from $19.89 \mathrm{ppbv}$ to $18.02 \mathrm{ppbv}$. Sources of NMHCs were then apportioned using the positive matrix factorization model. Four factors were resolved and identified, including vehicle exhaust, paint and solvents usage, gasoline evaporation, and biogenic emission. Relative contributions of these four sources were $52.5 \%, 20.6 \%, 18.3 \%$, and $8.6 \%$, respectively. After the implementation of this policy, relative contributions of gasoline evaporation in 1:00-4:00 increased from $20.2-22.7 \%$ to $25.4-28.2 \%$, while those for $16: 00-18: 00$ decreased from $16.8-18.7 \%$ to $13.9-15.7 \%$. The non-linear relationship of $\mathrm{O}_{3}$ with $\mathrm{NMHC}$ and $\mathrm{NO}_{\mathrm{x}}$ was investigated using a box model based on observations. Results suggest that $\mathrm{O}_{3}$ production was mainly controlled by NMHCs. Aromatics and alkenes were the key NMHC species in $\mathrm{O}_{3}$ formation. Furthermore, two scenarios of encouraging vehicles to refuel at night were designed to evaluate their impact on $\mathrm{O}_{3}$. The relative decreases of $\mathrm{O}_{3}$ peak concentrations were lower than $1 \%$, indicating that this policy had a limited impact on $\mathrm{O}_{3}$ during the observation period.
\end{abstract}

Keywords: gasoline evaporation; $\mathrm{O}_{3}$ sensitivity; $\mathrm{NMHCs}$; source apportionment

\section{Introduction}

Ground-level ozone $\left(\mathrm{O}_{3}\right)$ is a typical secondary pollutant that is formed by a series of photochemical reactions of non-methane hydrocarbons (NMHCs) and nitrogen oxides $\left(\mathrm{NO}_{\mathrm{x}}\right)$ under solar radiation [1,2]. Therefore, $\mathrm{O}_{3}$ usually displays higher concentrations at noon and early afternoon and lower values at night and in the morning [3,4]. A lot of studies reported that $\mathrm{O}_{3}$ production shows a highly non-linear relationship with NMHCs and $\mathrm{NO}_{\mathrm{x}}$ [5-7]. Due to the abundant $\mathrm{NO}_{\mathrm{x}}$ emission from vehicular exhaust, $\mathrm{O}_{3}$ formation tends to be mainly controlled by NMHCs (i.e., in the NMHCs-limited regime) in urban regions, which means that reduction of NMHCs emissions is more effective to control $\mathrm{O}_{3}$ pollution [5-7]. 
Ambient NMHCs can be emitted from biogenic sources and anthropogenic processes, such as vehicular exhaust, paint and solvents use, petrochemical and chemical industry, coal combustion, etc. [8,9]. Gasoline evaporation has been considered an important source of NMHCs in urban regions [10-12]. Alkanes and alkenes with 4 and 5 carbon atoms (C4-C5 alkanes and alkenes), especially pentanes, were reported to be the main components of NMHCs emitted from gasoline evaporation [11-13], and their evaporation rate would be promoted by high temperature [10,12]. In some cities of China, contributions of gasoline evaporation to ambient NMHCs can reach 10\% [14,15]. The process of automobile refueling during the daytime would result in NMHCs evaporation and further accelerate $\mathrm{O}_{3}$ production. To control $\mathrm{O}_{3}$ pollution, many cities of China introduced price incentives to encourage the public to refuel vehicles at night. However, few studies have evaluated the effectiveness of this policy to reduce $\mathrm{O}_{3}$ until now.

In this study, we assessed the impact of the policy encouraging vehicles refueling at night on $\mathrm{O}_{3}$ and NMHCs based on online measurements of $\mathrm{NMHCs}, \mathrm{NO}_{\mathrm{x}}$, and $\mathrm{O}_{3}$ during 1 May-31 July in 2019 and 2020 at an urban site of Ji'nan, Shandong Province. According to the Brief Report on Environmental Quality issued by the Ji'nan Municipal Bureau of Ecology and Environment (http://jnepb.jinan.gov.cn/col/col10451/index.html, accessed on 1 March 2021), the annual 90th percentiles of daily maximum $8 \mathrm{~h}$ moving average $\mathrm{O}_{3}$ concentrations (DMA-8h $\mathrm{O}_{3}$ ) ranged from $184 \mu \mathrm{g} / \mathrm{m}^{3}$ to $203 \mu \mathrm{g} / \mathrm{m}^{3}$ during 2015-2019, exceeding the second grade national ambient air quality standard $\left(160 \mu \mathrm{g} / \mathrm{m}^{3}\right)$. The days with $\mathrm{O}_{3}$ as the primary air pollutant accounted for $24.7-39.2 \%$ of total monitoring days. To control $\mathrm{O}_{3}$ and NMHCs pollution in summer, the Department of Ecological Environment of Shandong Province suggested petrol stations adopt preferential measures to encourage the public to refuel vehicles at night (20:00-23:00 and 0:00-6:00) on 11 June 2020 (http:/ / xxgk.sdein.gov.cn/_zfwj/lhh/202006/t20200612_3127944.html, accessed on 1 March 2021). Subsequently, some petrol stations belonging to China Petroleum and Chemical Corporation (Sinopec) and China National Petroleum Corporation (CNPC) began to adopt the price incentives for nighttime refueling from 16 June 2020. According to the statistics of 2019, Sinopec and CNPC accounted for about one-third of the number of petrol stations and about two-thirds of the total sale amount of oil in Jinan. The average refueling volumes at night in Ji'nan increased to $1.14 \times 10^{5} \mathrm{~L}$ during 17-23 June 2020, which was about $30 \%$ higher than the result for the week before the implementation of this policy (http://jinan.iqilu.com/jnms/2020/0806/4612917.shtml, accessed on 15 February 2021). Changes in ambient levels and diurnal variation patterns for $\mathrm{O}_{3}$ and NMHCs before and after the implementation of this policy were analyzed based on measurement data. NMHCs source apportionment and $\mathrm{O}_{3}$ formation sensitivity were then conducted using a receptor model and a box model based on observations (OBM), respectively. Furthermore, the impact of this policy on $\mathrm{O}_{3}$ concentrations was investigated by comparing the OBMsimulated $\mathrm{O}_{3}$ concentrations between the base scenario and two gasoline evaporation control scenarios.

\section{Methodology}

\subsection{Online Measurements of $\mathrm{O}_{3}$ and Its Precursors}

Ambient levels of $\mathrm{O}_{3}, \mathrm{NMHCs}, \mathrm{NO}_{\mathrm{x}}$, carbon monoxide (CO), and meteorological parameters were online measured during 1 May-31 July in 2019 and 2020 at an urban site in Ji'nan $\left(36.67^{\circ} \mathrm{N}, 117.06^{\circ} \mathrm{E}\right)$ (Figure 1). This site is located in the downtown area of Ji'nan city, which is surrounded by a campus, business district, and residential areas. The two nearest main roads are about $1.5 \mathrm{~km}$ and $1.7 \mathrm{~km}$ distant from this site in the east and south, respectively. Major gasoline stations in Jinan are shown by stars in Figure 1. The distances between this site and surrounding petrol stations are about $1-2 \mathrm{~km}$. 


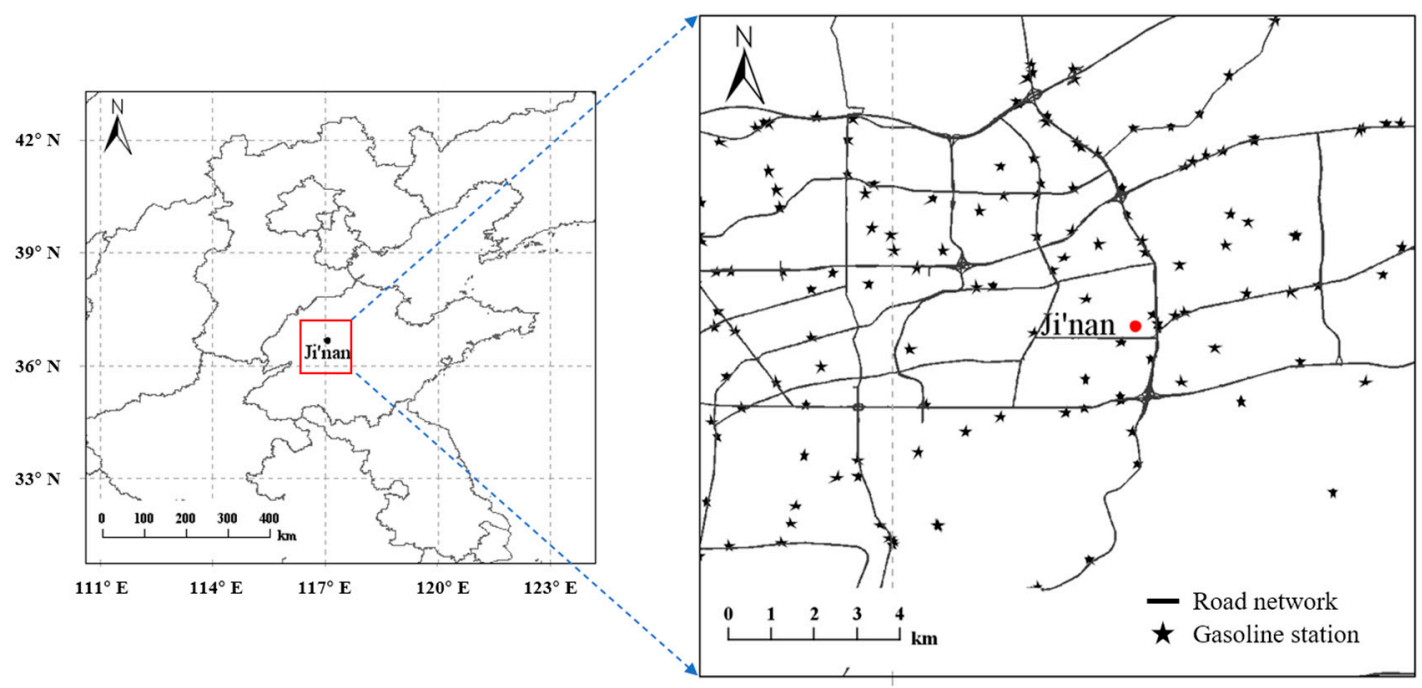

Figure 1. Locations of the measurement site and gasoline stations in Ji'nan.

Ambient NMHCs were pre-concentrated by two capillary columns filled with absorbents (enrichment trap and focus trap) at room temperature (about $25^{\circ} \mathrm{C}$ ), and then were vaporized and injected into a gas chromatography (GC) system equipped with a flame ionization detector (FID) and a mass spectrometer detector (MSD) (GCMS-QP2020, Shimadzu Cooperation, Kyoto City, Japan) for separation and detection. Except for the three species with two carbon atoms, the other target NMHCs were separated on a DB-1 column $(0.25 \mathrm{~mm} \times 60 \mathrm{~m} \times 1 \mu \mathrm{m}$, Agilent Inc., Santa Clara, CA, USA). The oven temperatures for the GC-MS /FID system initiated at $35^{\circ} \mathrm{C}$ which was held for $10 \mathrm{~min}$, then increased from $35{ }^{\circ} \mathrm{C}$ to $100{ }^{\circ} \mathrm{C}$ at $10{ }^{\circ} \mathrm{C} / \mathrm{min}$ and was held for $5 \mathrm{~min}$ at $100{ }^{\circ} \mathrm{C}$, then increased to $220^{\circ} \mathrm{C}$ at $10^{\circ} \mathrm{C} / \mathrm{min}$ and was then held for $3 \mathrm{~min}$ at $220^{\circ} \mathrm{C}$, followed by an increase to $240^{\circ} \mathrm{C}$ at $10^{\circ} \mathrm{C} / \mathrm{min}$, which was then held for $3.5 \mathrm{~min}$. Fifty-seven NMHC species were quantified by using this GC-MS/FID system, including 29 alkanes, 11 alkenes, acetylene, and 16 aromatics. The mixed 1-ppm standard gas for 57 NMHCs (Spectra gasses Inc., Branchburg, NJ, USA) was diluted to 6 calibration standards with mixing ratios of $0.5 \mathrm{ppbv}$, $2 \mathrm{ppbv}, 3 \mathrm{ppbv}, 4 \mathrm{ppbv}, 8 \mathrm{ppbv}$, and $10 \mathrm{ppbv}$. Correlation coefficient $(r)$ values of calibration curves ranged from 0.99 to 1.00 . The method detection limits (MDL) for these NMHC species were in the range of $0.009-0.161 \mathrm{ppbv}$.

Ambient concentrations of $\mathrm{O}_{3}, \mathrm{NO}_{x}$, and $\mathrm{CO}$ were online measured using an ultraviolet (UV) absorption spectrometer (Model T400, Teledyne API Inc., San Diego, CA, USA), a chemiluminescence NO- $\mathrm{NO}_{2}-\mathrm{NO}_{x}$ analyzer (Model T200, Teledyne API Inc., USA), and an infrared absorption spectrometer (Model T300, Teledyne API Inc., USA), respectively. Meteorological parameters were measured using a weather station (Met One Instruments Inc., Grants Pass, OR, USA), including wind speed and direction, temperature, and relative humidity.

\subsection{Models}

\subsubsection{Observation-Based Model (OBM)}

In this study, the relationship of $\mathrm{O}_{3}$ formation with its precursors was analyzed using a 0-dimension observations-based chemical transport box model that was developed by Cardelino and Chameides (1995) [16]. The $1 \mathrm{~h}$ average measurement data for $\mathrm{NMHCs}, \mathrm{NO}_{\mathrm{x}}$, $\mathrm{O}_{3}, \mathrm{CO}$, temperature, and relative humidity were inputted into the $\mathrm{OBM}$ to simulate the net production potential of $\mathrm{O}_{3}\left(P_{\mathrm{O} 3-\mathrm{NO}}\right)$ during the daytime (07:00-19:00). The following 
Equation (1) was used to calculate relative incremental reactivity (RIR) values for individual precursors $(X)$ :

$$
R I R(X)=\frac{\left(P_{\mathrm{O}_{3}-N O}(X)-P_{\mathrm{O}_{3}-N O}(X-\Delta X)\right) / P_{\mathrm{O}_{3}-N O}(X)}{\Delta S(X) / S(X)}
$$

where $\Delta X$ represents the change of concentration for $X . S(X)$ and $\Delta S(X)$ represent the source function of $X$ and its change attributed to $\Delta X$, respectively. $\Delta S(X) / S(X)$ was set as $10 \%$ in this study.

\subsubsection{Positive Matrix Factorization (PMF) Model}

The positive matrix factorization (PMF) model version 5.0 (PMF 5.0) that was developed by the U.S. Environmental Protection Agency (EPA) was applied in this study for NMHCs source apportionment. More details about the principles of PMF 5.0 were introduced in the user guide [17]. Briefly, the speciated NMHCs measurement data matrix $(x)$ can be decomposed into two matrices, i.e., factor contributions $(g)$ and factor profiles $(f)$ (Equation (2)).

$$
x_{i j}=\sum_{k=1}^{p} g_{i k} f_{k j}+e_{i j}
$$

where $x_{i j}$ means the concentration of $j$ species measured in $i$ sample. $g_{i k}$ and $f_{k j}$ represent the contribution of the $k$ source to $i$ sample and percentage of $j$ species in the $k$ source, respectively. $e_{i j}$ represents residual for $j$ species in $i$ sample; $p$ represents the number of factors.

\section{Results and Discussion}

\subsection{Meteorological Conditions during May-July of 2019 and 2020}

Meteorological parameters can influence the formation and removal processes of $\mathrm{O}_{3}$ [18]. Figure 2 shows wind roses during 1 May-15 June and 16 June-31 July of 2019 and 2020. The dominant wind direction was southeast through the whole two months of 2020. Similarly, the wind was also mainly from the southeast during 16 June-31 July, 2019. However, wind directions during 1 May-15 June 2019 showed a significant difference from the other three periods, which were mainly from southeast, northwest, and southwest. The average wind speeds during 16 June-31 July of 2019 and 2020 were both $2.0 \mathrm{~m} / \mathrm{s}$, slightly lower than the results for 1 May-15 June of 2019 and 2020 (2.3-2.5 m/s). This means that wind direction and speed during 1 May-15 June 2019 were different from results for the other three periods, which could result in a discrepancy of concentrations for $\mathrm{O}_{3}$ and its precursors.

To avoid meteorological influences on ambient levels of $\mathrm{O}_{3}$ and its precursors, those observation data under some meteorological conditions that are not beneficial for $\mathrm{O}_{3}$ local production were eliminated, mainly including those days with precipitation or daily average wind speed $\geq 3.4 \mathrm{~m} / \mathrm{s}$. There were $24,30,28$, and 25 days left during 1 May-15 June and 16 June-31 July of 2019 and 2020, respectively. Measurement data for meteorological parameters and mixing ratios of $\mathrm{O}_{3}$ and its precursors on these days were used to further discuss differences of meteorological conditions among these periods and evaluate the impact of this price incentives policy for nighttime refueling on $\mathrm{O}_{3}$ and $\mathrm{NMHCs}$.

As shown in Figure 3, the average daily temperature during 1 May-15 June and 16 June-31 July, 2020 was $25^{\circ} \mathrm{C}$ and $26^{\circ} \mathrm{C}$, respectively. There were 16 and 18 days with the daily maximum temperature (DMT) exceeding $30^{\circ} \mathrm{C}$ during these two periods. The cumulative hours of temperature exceeding $30{ }^{\circ} \mathrm{C}$ were 129 and 122 during these two periods, respectively. In 2019, the average daily temperature during 1 May-15 June and 16 June-31 July was $24{ }^{\circ} \mathrm{C}$ and $29^{\circ} \mathrm{C}$, respectively. There were 11 days $(90 \mathrm{~h})$ and 27 days (281 h) with DMT exceeding $30{ }^{\circ} \mathrm{C}$ during these two periods, respectively. Overall, the meteorological conditions in the two periods of 2020 were similar but showed significant differences to 2019. The average temperature and days and hours with temperature 
exceeding $30{ }^{\circ} \mathrm{C}$ during 16 June-31 July, 2019 were significantly higher than the results for the other three periods, which could be beneficial for $\mathrm{O}_{3}$ formation. However, days and cumulative hours with temperature exceeding $30^{\circ} \mathrm{C}$ for 1 May-15 June 2019 were lower than the other three periods. Based on the above results, it can be found that meteorological conditions, including wind direction and speed, and temperature, were similar between the two periods in 2020, but showed differences to those for 2019.
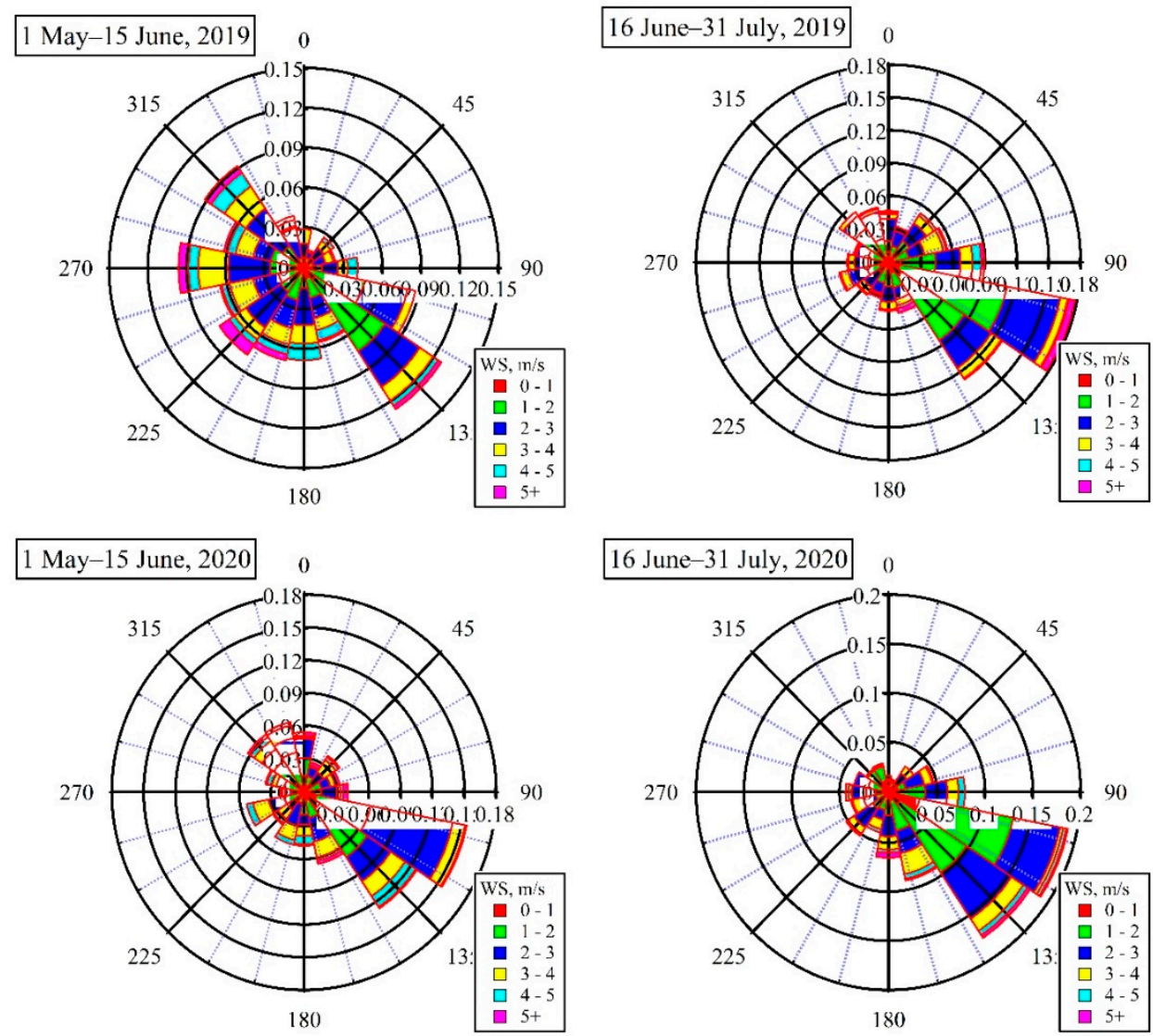

Figure 2. Comparison of wind rose plots during 1 May-15 June and 16 June-31 July of 2019 and 2020.

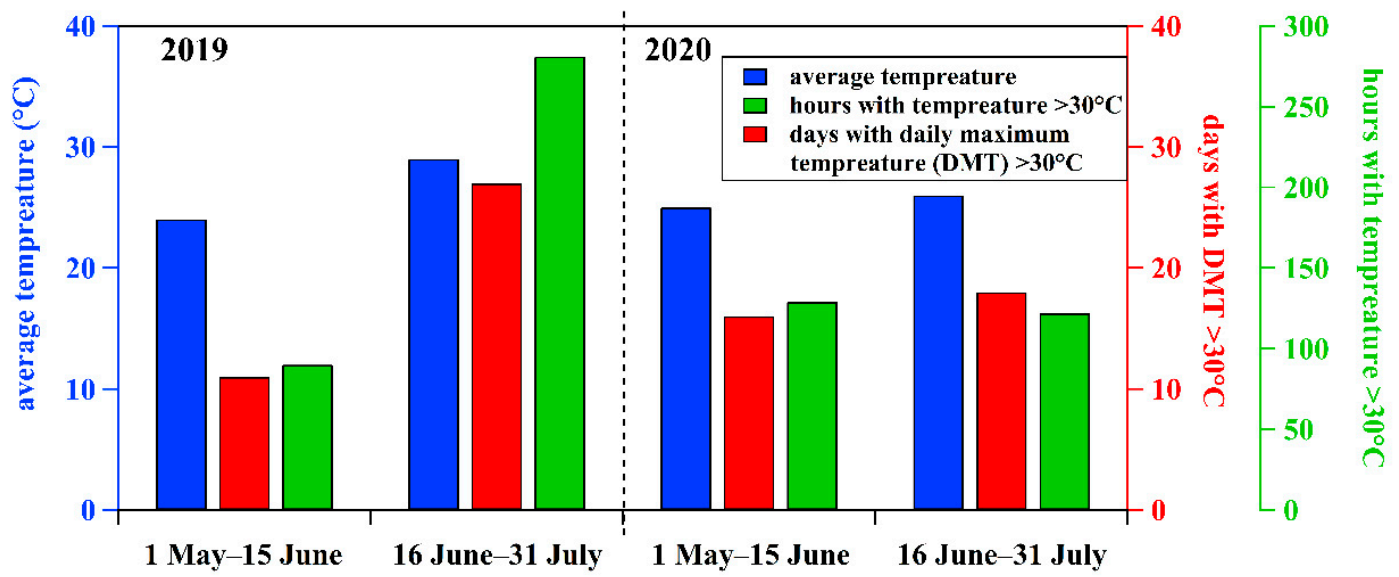

Figure 3. Comparisons of average temperature, hours with temperatures greater than $30{ }^{\circ} \mathrm{C}$, and days with daily maximum temperature (DMT) greater than $30^{\circ} \mathrm{C}$ among four periods (i.e., 1 May-15 June and 16 June-31 July 2019 and 2020) excluding those days with precipitation and wind speed larger than $3.4 \mathrm{~m} / \mathrm{s}$. 


\subsection{Ambient Levels of $\mathrm{O}_{3}$ and Non-Methane Hydrocarbons (NMHCs) during 2019 and 2020}

\subsubsection{Comparison of $\mathrm{O}_{3}$ Concentrations}

As shown in Figure 4, the average value of DMA- $8 \mathrm{~h} \mathrm{O}_{3}$ concentrations at the Ji'nan site during 1 May-15 June and 16 June-31 July 2020 was $198 \mu \mathrm{g} / \mathrm{m}^{3}$ and $181 \mu \mathrm{g} / \mathrm{m}^{3}$, respectively. There were 21 days and 18 days with DMA- $8 \mathrm{~h} \mathrm{O}_{3}$ concentrations exceeding $160 \mu \mathrm{g} / \mathrm{m}^{3}$ during these two periods, respectively. It seems that the average DMA- $8 \mathrm{~h} \mathrm{O}$ concentration decreased by $8.6 \%$ and non-attainment days were reduced by 3 after the implementation of the price incentives policy for nighttime refueling from 16 June 2020.

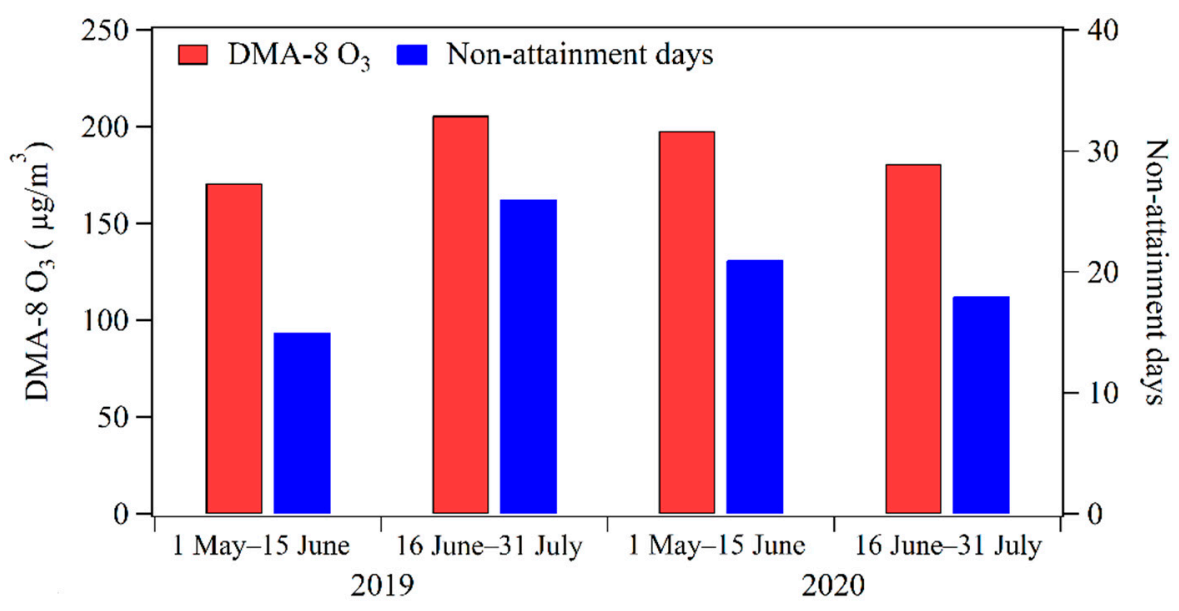

Figure 4. Comparison of DMA-8 $\mathrm{h} \mathrm{O}_{3}$ concentrations and $\mathrm{O}_{3}$ non-attainment days during 1 May-15 June and 16 June-31 July in 2019 and 2020.

The average DMA-8h O 3 concentration during 1 May-15 June 2020 was $27 \mu \mathrm{g} / \mathrm{m}^{3}$ higher than that for the same period in 2019, while the value for 16 June-31 July 2020 was $20 \mathrm{\mu g} / \mathrm{m}^{3}$ lower. The differences in meteorological conditions were possible causes for the discrepancy of $\mathrm{O}_{3}$ concentrations between 2019 and 2020. The average temperature showed the lowest value during 1 May-15 June 2019 but the highest value for 16 June-31 July 2019 (Figure 3). To avoid influences from meteorological conditions, further analysis of $\mathrm{O}_{3}$ and NMHCs mainly focused on the two periods before and after the implementation of this policy in 2020.

\subsubsection{Variations of NMHCs Mixing Ratios}

Average NMHCs mixing ratios at the Ji'nan site during 1 May-15 June and 16 June-31 July in 2019 and 2020 were compared in Figure 5. In general, the average mixing ratio of NMHCs during May-July 2020 was 18.95 ppbv, which was $17.8 \%$ higher than the result (16.09 ppbv) for 2019. For the two periods in 2020, the average NMHCs mixing ratio during 16 June-31 July was $18.02 \mathrm{ppbv}$, which was slightly lower than the result (19.89 ppbv) during 1 May-15 June.

As shown in Figure 5, the chemical compositions of NMHCs showed differences between 2019 and 2020. Relative contributions of aromatics decreased from 19.6-21.1\% in 2019 to $13.3-13.7 \%$ in 2020; meanwhile, relative contributions from C4-C5 alkanes increased from $18.8-21.1 \%$ to $24.6-25.9 \%$. For the two periods during 2020, the difference in NMHCs chemical composition was lower than that for 2019 versus 2020. During 1 May-15 June 2020, alkanes with 2 and 3 carbon atoms (i.e., C2-C3 alkanes) contributed $33.1 \%$ of total mixing ratios of NMHCs, followed by C4-C5 alkanes (24.6\%), aromatics (13.7\%), alkenes $(13.3 \%)$, alkanes with carbon atoms more than 5 (i.e., >C 5 alkanes) $(11.3 \%)$, and acetylene $(3.9 \%)$. After implementing the price incentives policy for nighttime refueling, relative contributions from C2-C3 alkanes, >C5 alkanes, and aromatics decreased to 31.6\%, 9.8\%, and $13.3 \%$, respectively. Meanwhile, relative contributions from C4-C5 alkanes, alkenes, and acetylene increased to $25.9 \%, 14.6 \%$, and $4.8 \%$, respectively. 


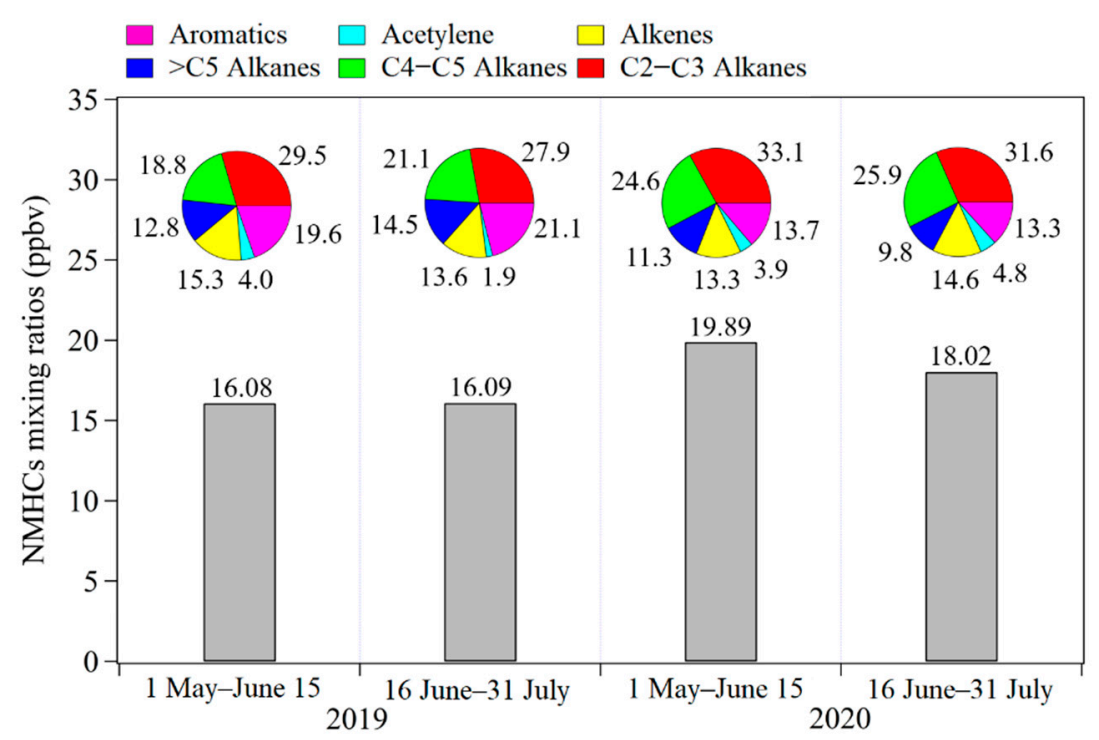

Figure 5. Comparison of average mixing ratios for non-methane hydrocarbons (NMHCs) during 1 May-15 June and 16 June-31 July in 2019 and 2020.

\subsubsection{Diurnal Variations of $\mathrm{O}_{3}$ and NMHCs Levels}

To further analyze the impact of this price incentives policy for nighttime refueling, the average diurnal variation patterns of $\mathrm{O}_{3}$ and NMHCs levels during 1 May-15 June and 16 June-31 July 2020 were compared in Figure 6. Mixing ratios of NMHCs in two periods both showed the maximum value in the morning rush hour (7:00-9:00), and then decreased gradually to the minimum value in the afternoon (13:00-15:00). This was probably due to the expansion of the boundary layer and the strong photochemical removal during noon and early afternoon [19]. Contrary to NMHCs mixing ratios, $\mathrm{O}_{3}$ concentrations showed a maximum value around 15:00 and then decreased gradually to low values during nighttime. This indicates that $\mathrm{O}_{3}$ at this site was mainly from secondary production.

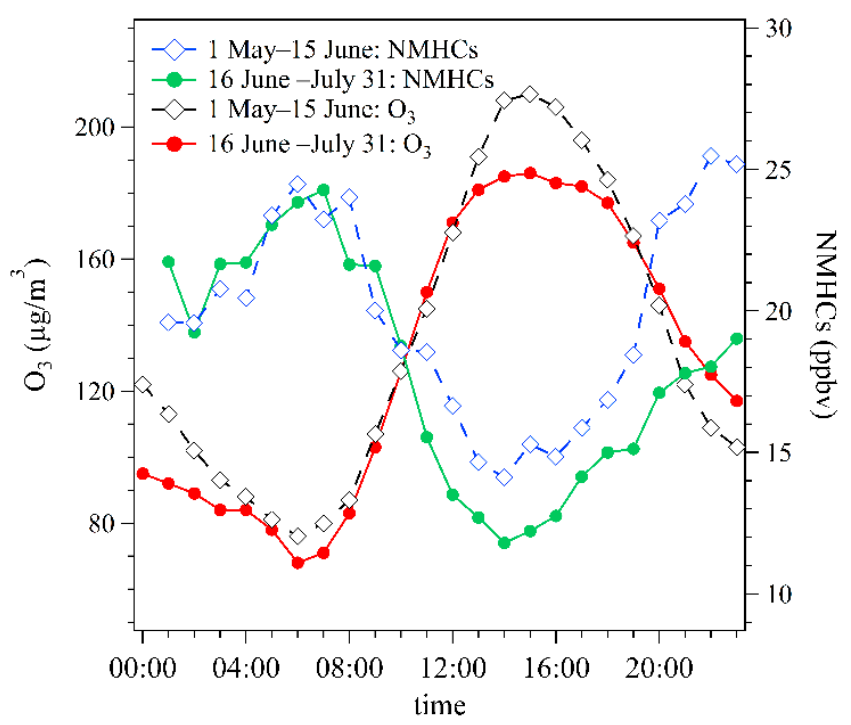

Figure 6. Average diurnal variation patterns of hourly average $\mathrm{O}_{3}$ concentrations and NMHCs mixing ratios during 1 May-15 June and 16 June-31 July of 2020.

During 1 May-15 June 2020, the average mixing ratios of NMHCs during daytime (06:00-20:00) and nighttime (20:00-06:00) were $18.25 \mathrm{ppbv}$ and $22.27 \mathrm{ppbv}$, respectively. The ratio of NMHCs mixing ratios during nighttime versus daytime of 1.22. After the implementation of this policy, the average mixing ratios of NMHCs during daytime and 
nighttime decreased to $16.75 \mathrm{ppbv}$ and $20.28 \mathrm{ppbv}$, respectively. The ratio of NMHCs mixing ratios during nighttime versus daytime was 1.21, close to the value for $1 \mathrm{May}-15$ June 2020. It should be noted that the relative decrease of NMHCs levels during 13:0017:00 between these two periods was $15 \%$, larger than that for nighttime $(9 \%)$. For $\mathrm{O}_{3}$, its hourly average concentrations during 13:00-17:00 decreased from 191-208 $\mu \mathrm{g} / \mathrm{m}^{3}$ during 1 May-15 June 2020 to $181-186 \mu \mathrm{g} / \mathrm{m}^{3}$ during 16 June-31 July 2020.

\subsubsection{Variations of Pentanes Mixing Ratios}

Pentanes (i.e., the sum of $i$-pentane and $n$-pentane) are important components of gasoline and, therefore, they are often used as tracers for gasoline evaporation [10,12]. Figure 7 compares average mixing ratios of pentanes and their percentages in total NMHCs during the daytime (06:00-20:00) and nighttime (20:00-06:00) of 1 May-15 June and 16 June-31 July 2020. Before the implementation of this policy, the average mixing ratios of pentanes during nighttime and daytime were $2.29 \mathrm{ppbv}$ and $1.66 \mathrm{ppbv}$, respectively. The ratio of daytime average level for pentanes versus nighttime was 1.38. During 16 June-31 July 2020, average mixing ratios of pentanes during nighttime and daytime decreased to $2.11 \mathrm{ppbv}$ and $1.56 \mathrm{ppbv}$, respectively. The ratio of daytime average level for pentanes versus nighttime was 1.35, close to the value for 1 May-15 June 2020. From the perspective of percentages of pentanes in total NMHCs, its values during nighttime and daytime of 16 June-31 July, 2020 were $10.7 \%$ and 9.6\%, higher than results for 1 May-15 June 2020 (9.8\% for the daytime; $8.9 \%$ for the nighttime), respectively. The ratio of average percentage for pentanes in total NMHCs during nighttime versus daytime increased from 1.12 to 1.15 after the implementation of this policy. This finding indicates that this policy possibly resulted in a slight increase of contributions from gasoline evaporation on ambient NMHCs during nighttime.

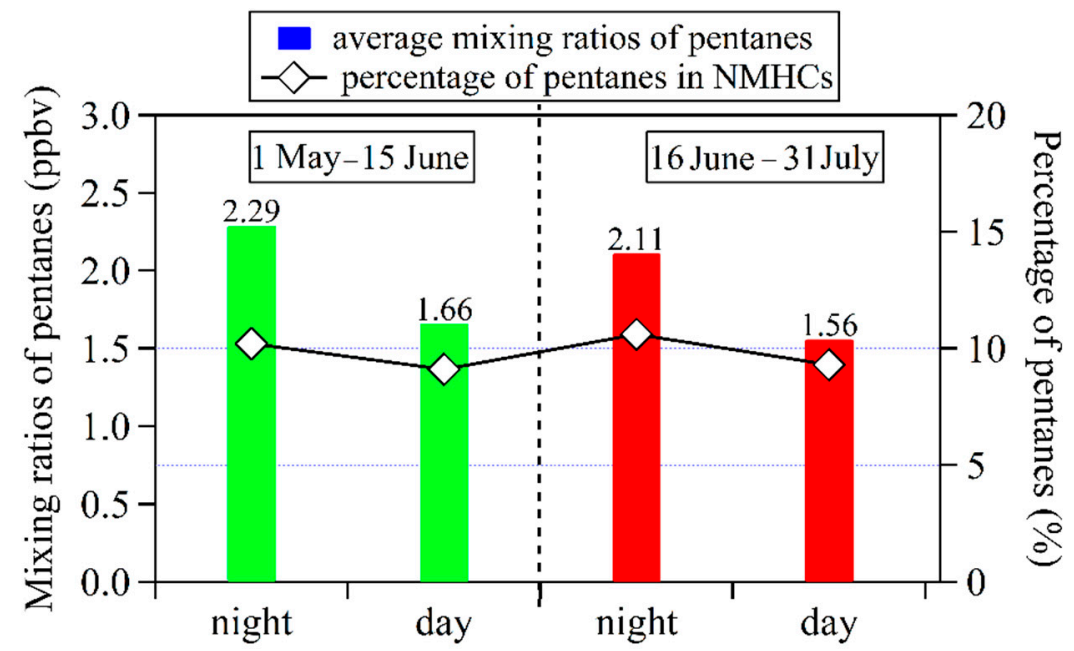

Figure 7. Average mixing ratios and percentages of pentanes during daytime (06:00-20:00) and nighttime (20:00-06:00) during 1 May-15 June and 16 June-31 July of 2020.

\subsection{NMHCs Sources Apportionment during May-July of 2020}

\subsubsection{Identification of PMF-Resolved Factors}

Values of signal versus noise (i.e., $S / N>5$ ), indications for sources, and high ambient mixing ratios were considered when selecting these NMHC species as inputs of the PMF model [17]. In this study, measurement data for 19 NMHC species were selected and inputted into the PMF model for source apportionment, including 8 alkanes, 6 aromatics, 4 alkenes, and acetylene (Figure 8 ). The PMF solutions with 3-8 factors were resolved and compared with each other. When factors were more than 4, the PMF-resolved solutions were hardly explained by individual sources. Therefore, the 4 -factor PMF solu- 
tion was used for source apportionment. Chemical profiles of these factors are shown in Figure 8a-d.
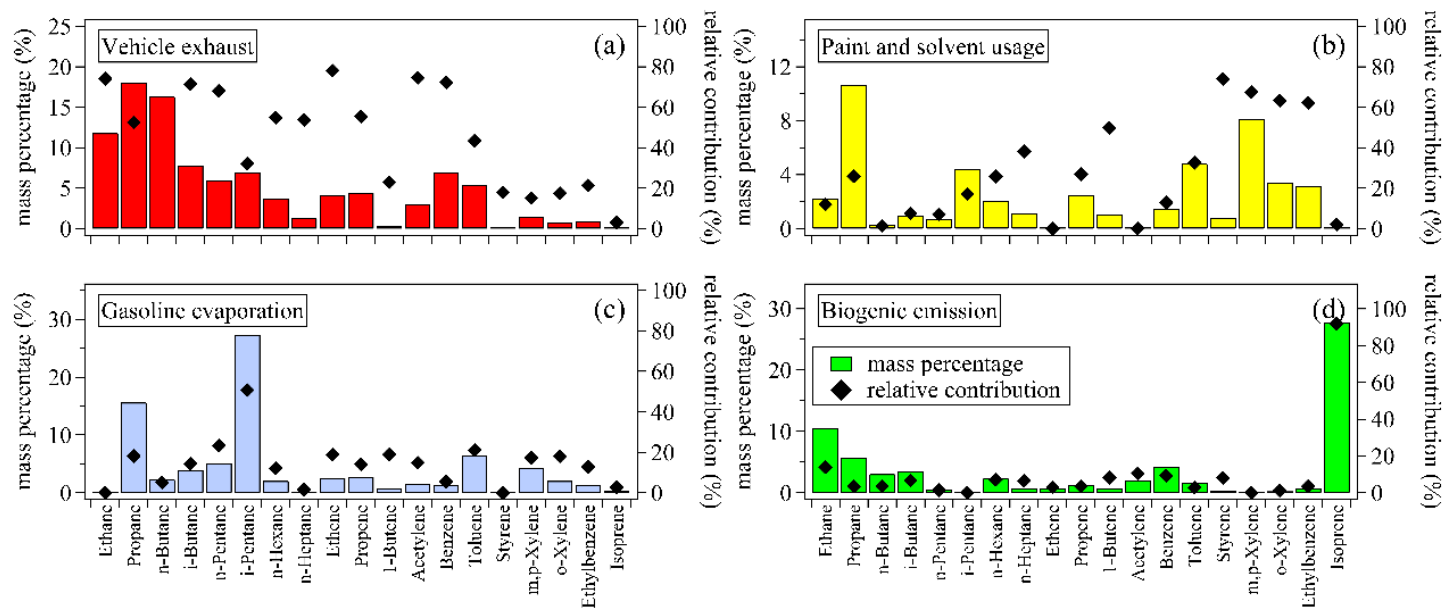

Figure 8. Chemical profiles of 4 factors resolved by the positive matrix factorization (PMF) model. (a) vehicle exhaust (red), (b) paint and solvent usage (yellow), (c) gasoline evaporation (blue), and (d) biogenic emission (green). The bars mean percentages of individual species in the summed mass concentrations of 19 NMHCs for each factor. The filled diamonds represent the relative contributions of each factor to the total measured mass concentrations for individual NMHC species.

Factor 1 was characterized by the high abundances of $\mathrm{C} 2-\mathrm{C} 4$ alkanes, $\mathrm{C} 6-\mathrm{C} 7$ alkanes, ethylene, acetylene, and benzene, with relative contributions of $52.5-90.1 \%, 53.8-54.9 \%$, $78.1 \%, 72.3 \%$, and $74.6 \%$, respectively. These species were reported to be important components of NMHCs emitted from vehicle exhaust [11,20-22], and thus this factor was considered vehicle exhaust. For factor 2, its relative contributions to C7-C8 aromatics, including toluene, ethylbenzene, xylenes, and styrene, showed high values of 32.6-73.9\%. Aromatics are important components of paint and solvents, which are widely used in industrial processes, painting, coating, and household products, etc. [23,24]. Therefore, this factor was identified as paint and solvent usage. Factor 3 was characterized by its high relative contribution (50.7\%) to $i$-pentane, which was an important component of gasoline $[13,21]$. Therefore, this factor was identified as gasoline evaporation. Factor 4 was characterized by its high relative contribution (91.9\%) to isoprene, which is the most important NMHC species from biogenic emissions [25]. In the daytime of summer, the biogenic source was usually considered as the largest contributor to isoprene [26], and thus factor 4 was identified as biogenic emission.

3.3.2. Relative Contributions of Individual Sources to NMHCs Levels and Ozone Formation Potential (OFP) during May-July of 2020

The average relative contributions of 4 sources to the summed mass concentrations of 19 NMHC species during May-July 2020 are shown in Figure 9a. Vehicle exhaust was the dominant source of NMHCs, with a relative contribution of $52.5 \%$, followed by paint and solvent usage (20.6\%), gasoline evaporation (18.3\%), and biogenic emission (8.6\%). Figure $9 \mathrm{~b}, \mathrm{c}$ compare the sources of NMHCs before and after the implementation of this policy. Relative contributions of vehicle exhaust were close between these two periods. Gasoline evaporation contributed $18.7 \%$ and $17.9 \%$ of NMHCs before and after the implementation of this policy. Meanwhile, relative contributions of biogenic emission increased from $7.5 \%$ during 1 May-15 June to $10.1 \%$ during 16 June- 31 July, while relative contributions of paint and solvent usage decreased from $22.2 \%$ to $18.6 \%$. 
(a)

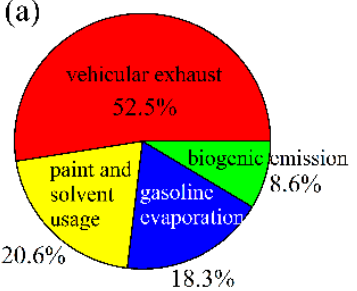

(d)

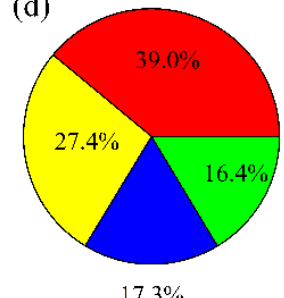

(b)

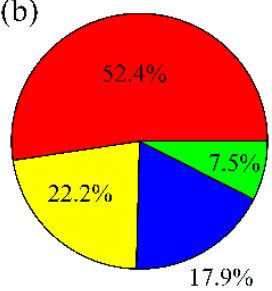

(e)

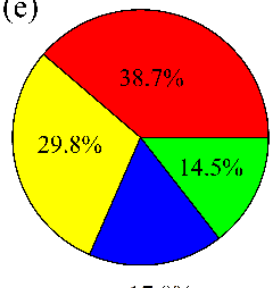

(c)

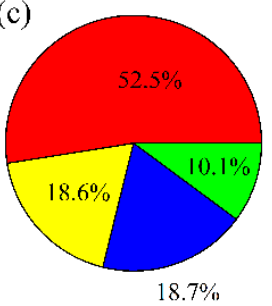

(f)

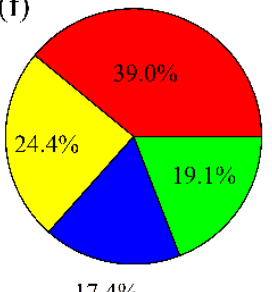

Figure 9. Relative contributions of 4 sources to total mass concentrations and ozone formation potential (OFP) of 19 NMHC species. (a) NMHCs mass concentrations for 1 May-31 July, (b) 1 May-15 June, and (c) 16 June-31 July 2020, (d) OFP for 1 May-31 July, (e) 1 May-15 June, and (f) 16 June-31 July 2020. The red, yellow, blue, and green colors mean that vehicular exhaust, paint and solvent usage, gasoline evaporation, and biogenic emission.

To find out the reason why the relative contribution of gasoline evaporation increased after the implementation of this policy, changes of mass concentrations for 4 PMF-resolved factors were further compared. The total mass concentration of $19 \mathrm{NMHC}$ decreased from $37.08 \mu \mathrm{g} / \mathrm{m}^{3}$ to $35.64 \mu \mathrm{g} / \mathrm{m}^{3}$ after the implementation of this policy. However, mass concentrations from gasoline evaporation were close during these two periods, with respective values of $6.63 \mu \mathrm{g} / \mathrm{m}^{3}$ and $6.67 \mu \mathrm{g} / \mathrm{m}^{3}$. Meanwhile, NMHCs concentrations contributed by vehicle exhaust decreased from $19.43 \mu \mathrm{g} / \mathrm{m}^{3}$ to $18.71 \mu \mathrm{g} / \mathrm{m}^{3}$, paint and solvent usage decreased from $8.23 \mu \mathrm{g} / \mathrm{m}^{3}$ to $6.64 \mu \mathrm{g} / \mathrm{m}^{3}$, and biogenic emission increased from $2.79 \mu \mathrm{g} / \mathrm{m}^{3}$ to $3.62 \mu \mathrm{g} / \mathrm{m}^{3}$, respectively. These results suggest that NMHCs concentrations from gasoline evaporation did not significantly decrease after the implementation of this policy, whereas relative contributions of gasoline evaporation showed an increase due to the decrease of NMHCs concentrations from other sources.

Ozone formation potential (OFP) of individual NMHC species was calculated using the following equation $\mathrm{OFP}=\mathrm{NMHC}_{i} \times \mathrm{MIR}_{i}$, where $\mathrm{NMHC}_{i}$ was the mass concentration of individual $19 \mathrm{NMHC}$ species, $\mathrm{MIR}_{i}$ was the maximum incremental reactivity coefficient of individual NMHC species simulated by Venecek et al. (2018) [27]. Relative contributions of 4 individual PMF-resolved sources to the total OFP of 19 NMHCs were shown in Figure $9 \mathrm{~d}$. Biogenic emission has a higher relative contribution to OFP $(16.4 \%)$ than that for mass concentration of NMHCs, due to the high reactivity of isoprene. For the three anthropogenic sources, vehicle exhaust was the largest contributor to OFP $(39.0 \%)$, followed by paint and solvent usage (27.4\%) and gasoline evaporation (17.3\%). Figure 9e,f compare the relative contributions of individual sources to OFP before and after the implementation of this policy. Relative contributions of vehicle exhaust to OFP were close between these two periods, with respective values of $38.7 \%$ and $39.0 \%$. Relative contributions of gasoline evaporation to OFP were $17.0 \%$ and $17.4 \%$ during these two periods, respectively. Relative contributions of biogenic emission increased from 14.5\% during 1 May-15 June 2020 to $19.1 \%$ during 16 June-31 July 2020, while relative contributions of paint and solvent usage decreased from $29.8 \%$ to $24.4 \%$.

To further investigate the impact of this price incentive policy for nighttime refueling, the average diurnal variation patterns of relative contributions from gasoline evaporation to NMHCs mass concentrations were compared before and after the implementation of this policy (Figure 10). Gasoline evaporation showed higher relative contributions during 
the nighttime and morning and then decreased gradually to the minimum value in the afternoon (around 16:00-18:00) during both periods. After the implementation of this policy, relative contributions of gasoline evaporation were in the range of $25.4-28.2 \%$ in the early morning (1:00-4:00), while the values for 1 May-15 June were $20.2-22.7 \%$. Meanwhile, relative contributions of gasoline evaporation in the afternoon (16:00-18:00) were in the range of $13.9-15.7 \%$, lower than results for 1 May-15 June, with values of $16.8-18.7 \%$. These findings indicate that this policy possibly influenced the diurnal distribution of NMHCs emissions from gasoline evaporation.
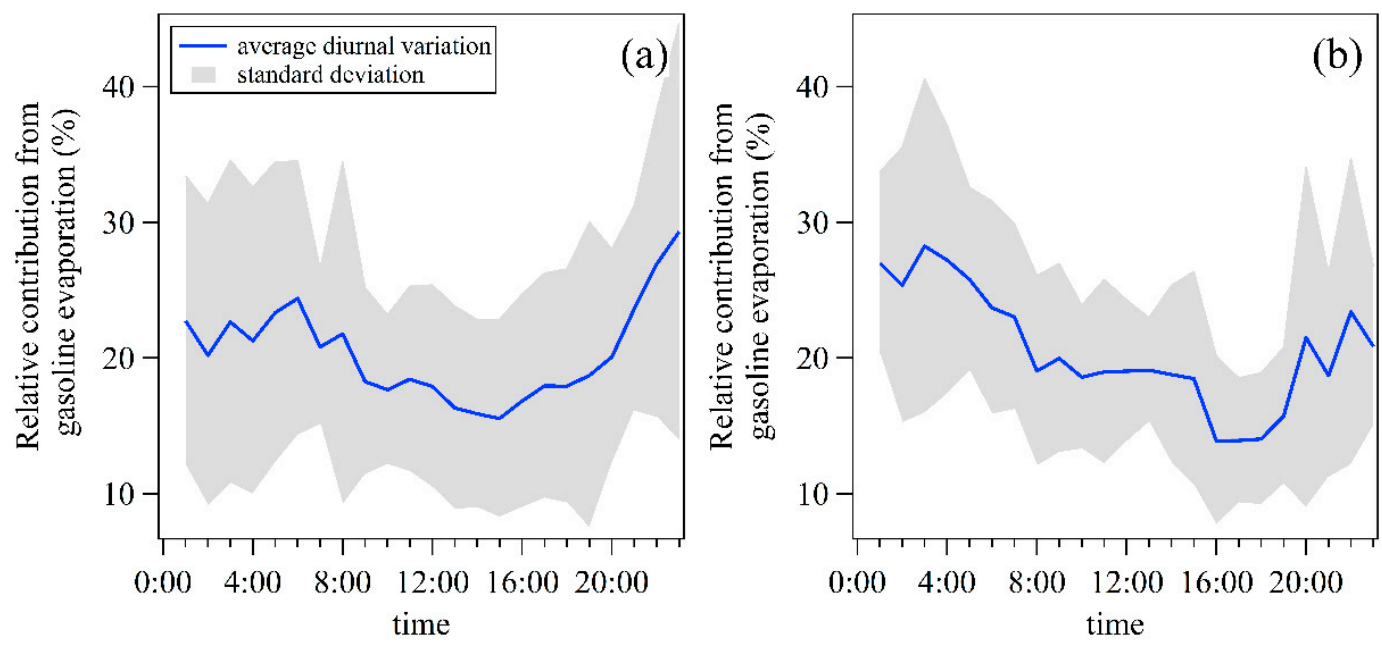

Figure 10. Average diurnal variation patterns of relative contributions from gasoline evaporation to NMHCs mass concentrations during (a) 1 May-15 June and (b) 16 June-31 July of 2020.

\section{4. $\mathrm{O}_{3}$ Formation Analysis during 2020}

3.4.1. Sensitivity of $\mathrm{O}_{3}$ Production of NMHCs and $\mathrm{NO}_{x}$

The $\mathrm{O}_{3}$ concentrations measured in this study showed a negative correlation $\left(r=-0.508^{* *}\right)$ with $\mathrm{NO}_{\mathrm{x}}$ concentrations but a positive correlation $\left(r=0.202^{* *}\right)$ with the ratio of $\mathrm{NO}_{2}$ versus $\mathrm{NO}_{\mathrm{x}}\left(\mathrm{NO}_{2} / \mathrm{NO}_{\mathrm{x}}\right)$ which was often used to indicate aging of air masses [28]. Furthermore, the non-linear relationship of $\mathrm{O}_{3}$ formation with NMHCs and $\mathrm{NO}_{x}$ during May-July 2020 was analyzed using two methods, including the RIR values (Equation (1)) and the empirical kinetic modeling approach (EKMA) based on the OBM. The EKMA was modeled based on $20 \times 20$ combinations of anthropogenic NMHCs and $\mathrm{NO}_{\mathrm{x}}$ reduction scenarios. Each scenario represented a 5\% reduction of anthropogenic NMHCs and $\mathrm{NO}_{x}$ from $0 \%$ to $100 \%$.

Figure 11a shows the isopleth diagram of DMA- $8 \mathrm{~h} \mathrm{O} \mathrm{O}_{3}$ with relative reductions of anthropogenic NMHCs and $\mathrm{NO}_{x}$ (i.e., the EKMA plot). This plot can be divided into 2 parts by the ridgeline (the dashed black line in Figure 11a). The upper-left part represents $\mathrm{O}_{3}$ formation is in the NMHCs-limited regime, while the lower-right part represents $\mathrm{O}_{3}$ formation in the $\mathrm{NO}_{x}$-limited regime. Based on the EKMA plot, the $\mathrm{O}_{3}$ formation in Ji'nan during May-July 2020 was in the NMHCs-limited regime. This means that $\mathrm{O}_{3}$ concentrations would decrease by reducing anthropogenic NMHCs (AHC), while a small reduction of $\mathrm{NO}_{x}$ would lead to an increase in $\mathrm{O}_{3}$ concentration. This price incentive policy encouraged the public to refuel vehicles at night and could reduce NMHCs levels in the daytime to some extent, and therefore this policy could inhibit the formation of $\mathrm{O}_{3}$ during the daytime. 

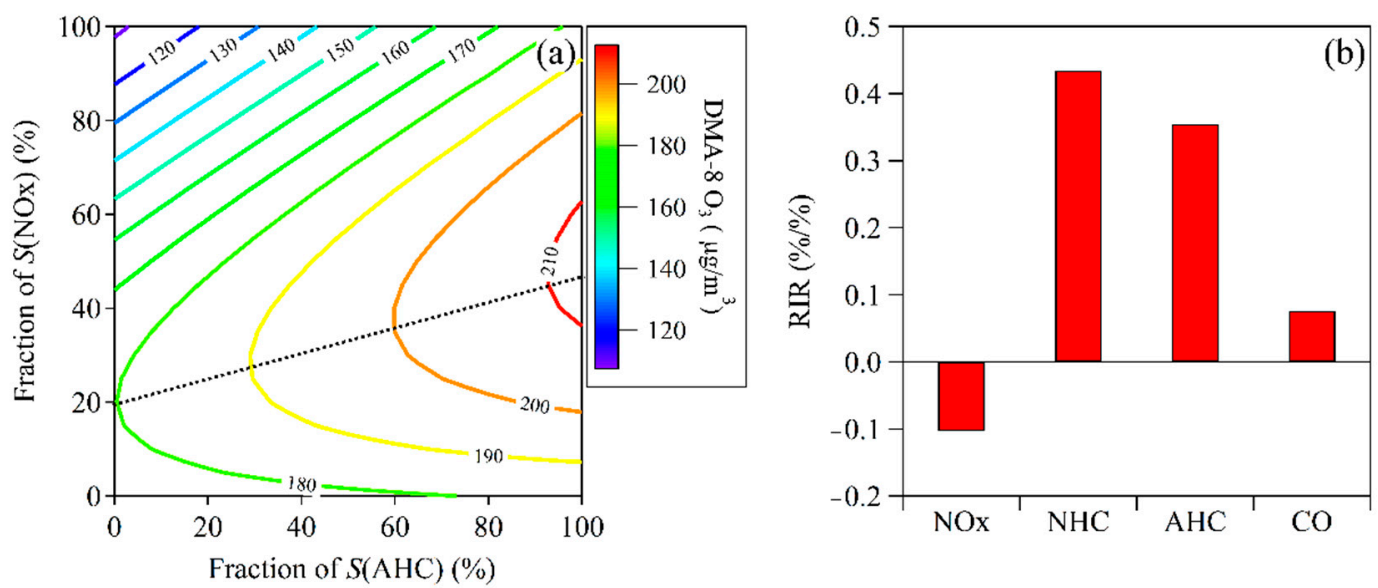

Figure 11. (a) Relationship of DMA-8h $\mathrm{O}_{3}$ concentrations with relative change of $S(\mathrm{AHC})$ and $S\left(\mathrm{NO}_{\mathrm{x}}\right)$ and (b) average relative incremental reactivity (RIR) values for $\mathrm{NO}_{x}, \mathrm{NHC}$ (i.e., isoprene), anthropogenic $\mathrm{NMHCs}(\mathrm{AHC})$, and CO during May-July of 2020.

Figure $11 \mathrm{~b}$ shows the RIR values for $\mathrm{NO}_{\mathrm{x}}, \mathrm{NHC}$ (i.e., isoprene), $\mathrm{AHC}$, and $\mathrm{CO}$ that were calculated by the OBM. The RIR value of $\mathrm{NO}_{x}$ was negative $(-0.103 \% / \%)$, indicating that reducing $\mathrm{NO}_{x}$ possibly resulted in $\mathrm{O}_{3}$ increase. Contrary to $\mathrm{NO}_{x}$, the RIR values of $\mathrm{NHC}, \mathrm{AHC}$, and CO were all positive, which suggests that the reduction of NMHCs and $\mathrm{CO}$ would decrease $\mathrm{O}_{3}$ formation. Although the RIR value for $\mathrm{CO}$ was also positive, its value was only $0.076 \% / \%$, significantly lower than the RIR values for AHC $(0.354 \% / \%)$ and NHC $(0.434 \% / \%)$. This implies that ambient NMHCs played a more important role in $\mathrm{O}_{3}$ formation than $\mathrm{CO}$. Considering it was hard to reduce biogenic emission, reduction of AHC would be the relatively effective way to control $\mathrm{O}_{3}$ pollution.

To determine the key NMHC species in $\mathrm{O}_{3}$ formation during May-July of 2020, the RIR values for individual NMHC species were calculated using the OBM. The AHC species with the top 10 largest RIR values included 5 aromatics, 4 alkenes, and propane, indicating that aromatics and alkenes played key roles in $\mathrm{O}_{3}$ formation. Propene had the largest RIR value $(0.087 \% / \%)$, followed by $m, p$-xylene $(0.058 \% / \%)$, $o$-xylene $(0.027 \% / \%)$, 1-butene $(0.020 \% / \%), 1,2,4$-trimethylbenzene $(0.017 \% / \%)$, ethylene $(0.014 \% / \%)$, 3-ethyltoluene $(0.013 \% / \%)$, propane $(0.012 \% / \%), 1,3$-butadiene $(0.011 \% / \%)$, and 1,2,4-trimethylbenzene $(0.010 \% / \%)$, respectively. The RIR values for $i$-pentane and $n$-pentane were $0.008 \% / \%$ and $0.003 \% / \%$, respectively.

\subsubsection{The Impact of This Policy on Simulated $\mathrm{O}_{3}$ Concentrations}

To quantitatively evaluate the impact of this policy on $\mathrm{O}_{3}$ concentrations, two scenarios for gasoline evaporation control were designed. The simulated $\mathrm{O}_{3}$ concentrations by the OBM were compared between the baseline scenario and two control scenarios. The measurement data of $\mathrm{O}_{3}$ and its precursors during 1 May-15 June 2020 (i.e., before the implementation of this policy) were used as inputs for the baseline scenario. According to the above results in Section 3.2.4, the ratio of pentanes percentages in NMHCs during the nighttime versus daytime increased by about $3 \%$ after the implementation of this policy. Therefore, scenario 1 assumed that the relative contribution of gasoline evaporation to NMHCs decreased by $1.5 \%$ during the daytime and increased by $1.5 \%$ during the nighttime. Scenario 2 assumed that stricter control measures or preferential policies were implemented to encourage the public to refuel vehicles at night, and then the relative contribution of gasoline evaporation to NMHCs decreased by $30 \%$ during the daytime and increased by $30 \%$ during the nighttime. It should be pointed out that the concentrations of NMHCs from gasoline evaporation changed in scenario 1 and scenario 2, while concentrations of NMHCs from other sources, as well as levels of $\mathrm{NO}_{x}, \mathrm{CO}$, and meteorological parameters, did not change among the baseline scenario and two control scenarios. 
Figure 12 shows the average diurnal variation patterns of decreases of $\mathrm{O}_{3}$ concentrations simulated by the OBM between the baseline scenario and two control scenarios for all days and non-attainment days during 1 May-15 June 2020. For scenario 1, the average peak concentration of $\mathrm{O}_{3}$ decreased by $0.16 \pm 0.15 \mu \mathrm{g} / \mathrm{m}^{3}$ at $15: 00$ and $0.19 \pm 0.15 \mu \mathrm{g} / \mathrm{m}^{3}$ at 18:00 for all days (Figure 12a) and non-attainment days (Figure 12b), respectively. In scenario 2, the average peak concentration of $\mathrm{O}_{3}$ at $17: 00$ decreased by $2.25 \pm 1.40 \mu \mathrm{g} / \mathrm{m}^{3}$ and $2.76 \pm 1.19 \mu \mathrm{g} / \mathrm{m}^{3}$ for all days and non-attainment days, respectively. These findings suggest that this price incentives policy for nighttime refueling would decrease $\mathrm{O}_{3}$ peak concentrations in the early afternoon. However, the relative decreases of $\mathrm{O}_{3}$ peak concentrations were lower than $1 \%$ for scenario 1 . This means that the current policy had a limited impact on $\mathrm{O}_{3}$ concentrations at the Ji'nan site during the observation period of 2020.
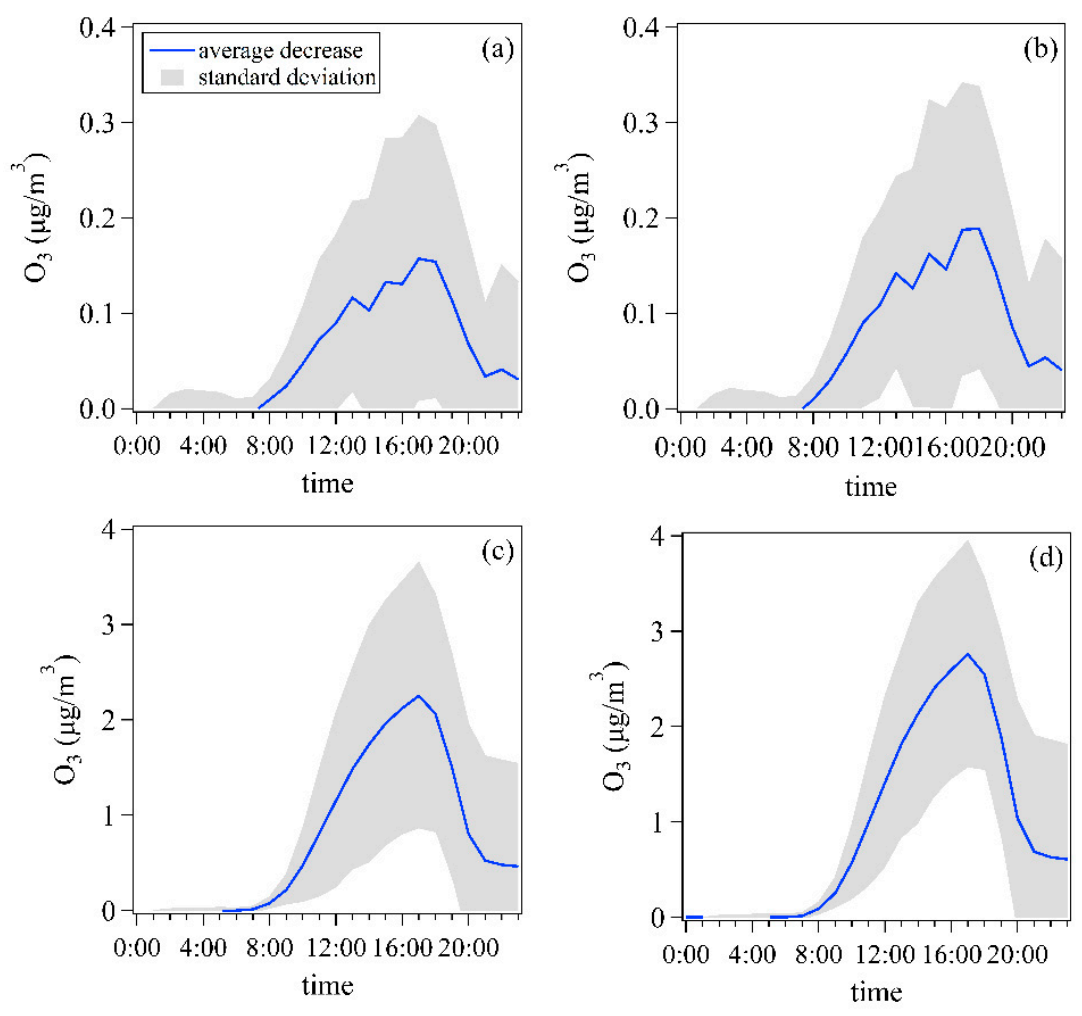

Figure 12. Average diurnal variation patterns of decreases for $\mathrm{O}_{3}$ concentrations simulated by the observation-based model (OBM) for all days and non-attainment days in 1 May-15 June 2020. (a) the scenario 1 versus baseline scenario for all days, (b) the scenario 1 versus baseline scenario for non-attainment days, (c) the scenario 2 versus baseline scenario for all days, (d) the scenario 2 versus baseline scenario for non-attainment days.

\section{Conclusions}

The price incentives policy for nighttime refueling was implemented from 16 June 2020 in Ji'nan to control $\mathrm{O}_{3}$ pollution. The impact of this policy on $\mathrm{O}_{3}$ and NMHCs was evaluated based on online observation data of $\mathrm{O}_{3}, \mathrm{NMHCs} \mathrm{NO}_{x}$, and $\mathrm{CO}$ at an urban site in Ji'nan during May-July of 2019 and 2020.

Changes in $\mathrm{O}_{3}$ concentrations, NMHCs levels, and sources: The average DMA-8 $\mathrm{O}_{3}$ concentration during 16 June-31 July 2020 decreased by $8.6 \%$ to $181 \mu \mathrm{g} / \mathrm{m}^{3}$. Meanwhile, the average mixing ratios of NMHCs decreased by $9.5 \%$ to $18.02 \mathrm{ppbv}$. The PMF model was applied for NMHCs source apportionment. Four source categories were identified, including vehicle exhaust, paint and solvent use, gasoline evaporation, and biogenic emission. Vehicle exhaust was the dominant source to NMHCs, with a relative contribution of $52.5 \%$, followed by paint and solvent use (20.6\%), gasoline evaporation $(18.3 \%)$, and biogenic emission (8.6\%). After the implementation of this policy, relative contributions 
of gasoline evaporation in 1:00-4:00 increased from $20.2-22.7 \%$ to $25.4-28.2 \%$, while those in $16: 00-18: 00$ decreased from $16.8-18.7 \%$ to $13.9-15.7 \%$. This indicates that this policy possibly influenced the diurnal distribution of gasoline evaporation.

$\mathrm{O}_{3}$ sensitivity to its precursors: The RIR values for $\mathrm{AHC}, \mathrm{NHC}$, and $\mathrm{CO}$ were positive, while the RIR value for $\mathrm{NO}_{x}$ was negative, suggesting that $\mathrm{O}_{3}$ production was in the NMHCs-limited regime. The EKMA plot suggests that reducing AHC was an effective way to control $\mathrm{O}_{3}$. The AHC species with the top ten largest RIR values included 5 aromatics, 4 alkenes, and propane, indicating that aromatics and alkenes are key species in $\mathrm{O}_{3}$ production. The summed RIR value for $i$-pentane and $n$-pentane was $0.011 \% / \%$, close to the value for propane.

Impact of this policy on $\mathrm{O}_{3}$ concentrations: Two scenarios for gasoline evaporation control were designed and simulated using the OBM. The measurement data of $\mathrm{O}_{3}$ and its precursors during 1 May-15 June 2020 were used as inputs of the baseline scenario. Scenario 1 and 2 assumed that the relative contribution of gasoline evaporation to NMHCs decreased by $1.5 \%$ and $30 \%$ during the daytime and increased by $1.5 \%$ and $30 \%$ during the nighttime, respectively. In scenarios 1 and $2, \mathrm{O}_{3}$ peak concentrations decreased by $0.16 \pm 0.15 \mu \mathrm{g} / \mathrm{m}^{3}$ and $2.25 \pm 1.40 \mu \mathrm{g} / \mathrm{m}^{3}$, with relative decline lower than $1 \%$. This means that the current price incentives policy for nighttime refueling had a limited impact on $\mathrm{O}_{3}$ concentrations during the observation period.

Author Contributions: Conceptualization, W.C. (Wenxuan Chai), M.W. and G.T.; data curation, Y.S., Y.H., K.H. and S.L.; formal analysis, Y.S., Y.H. and S.L.; investigation, W.C. (Wenxuan Chai); methodology, W.C (Wenxuan Chai) and W.C. (Wentai Chen); software, W.C. (Wentai Chen) and K.H.; Writing-Original draft preparation, W.C. (Wenxuan Chai) and Y.S.; Writing-Review and Editing, M.W. and G.T.; funding acquisition, G.T. and M.W. All authors have read and agreed to the published version of the manuscript.

Funding: This research was funded by the National Key Research and Development Program of China (No. 2018YFC0213201) and the National Natural Science Foundation of China (No. 41505113).

Institutional Review Board Statement: Not applicable.

Informed Consent Statement: Not applicable.

Data Availability Statement: Not applicable.

Acknowledgments: We are grateful for financial support from the National Key Research and Development Program of China (No. 2018YFC0213201) and the National Natural Science Foundation of China (No. 41505113).

Conflicts of Interest: The authors declare no conflict of interest.

\section{References}

1. Atkinson, R. Atmospheric chemistry of VOCs and NOx. Atmos. Environ. 2000, 34, 12-14. [CrossRef]

2. Guo, H.; Ling, Z.; Cheng, H.; Simpson, I.; Lyu, X.; Wang, X.; Shao, M.; Lu, H.; Ayoko, G.; Zhang, Y.; et al. Tropospheric volatile organic compounds in China. Sci. Total Environ. 2017, 574, 1021-1043. [CrossRef]

3. Barrett, B.; Raga, G. Variability of winter and summer surface ozone in Mexico City on the intraseasonal timescale. Atmos. Chem. Phys. 2016, 16, 15359-15370. [CrossRef]

4. Yang, Y.; Shao, M.; Keßel, S.; Li, Y.; Lu, K.; Lu, S.; Williams, J.; Zhang, Y.; Zeng, L.; Nölscher, A.; et al. How the OH reactivity affects the ozone production efficiency: Case studies in Beijing and Heshan, China. Atmos. Chem. Phys. 2017, 17, 7127-7142. [CrossRef]

5. Kleinman, L.; Daum, P.; Lee, Y.; Nunnermacker, L.; Springston, S.; Weinstein-Lloyd, J.; Rudolph, J. A comparative study of ozone production in five U.S. metropolitan areas. J. Geophys. Res. Atmos. 2005, 110, D02301. [CrossRef]

6. Zhang, Y.; Su, H.; Zhong, L.; Cheng, Y.; Zeng, L.; Wang, X.; Xiang, Y.; Wang, J.; Gao, D.; Shao, M.; et al. Regional ozone pollution and observation-based approach for analyzing ozone-precursor relationship during the PRIDE-PRD2004 campaign. Atmos. Environ. 2008, 42, 6203-6218. [CrossRef]

7. Tan, Z.; Lu, K.; Dong, H.; Hu, M.; Li, X.; Liu, Y.; Lu, S.; Shao, M.; Su, R.; Wang, H.; et al. Explicit diagnosis of the local ozone production rate and the ozone-NO $\mathrm{NO}_{\mathrm{x}}$-VOC sensitivities. Sci. Bull. 2018, 63, 1067-1076. [CrossRef]

8. Kansal, A. Sources and reactivity of NMHCs and VOCs in the atmosphere: A review. J. Hazard. Mater. 2009, 166, 17-26. [CrossRef] 
9. Li, M.; Zhang, Q.; Zheng, B.; Tong, D.; Lei, Y.; Liu, F.; Hong, C.; Kang, S.; Yan, L.; Zhang, Y.; et al. Persistent growth of anthropogenic non-methane volatile organic compound (NMVOC) emissions in China during 1990-2017: Drivers, speciation and ozone formation potential. Atmos. Chem. Phys. 2019, 19, 8897-8913. [CrossRef]

10. Gentner, D.; Harley, R.; Miller, A.; Goldstein, A. Diurnal and seasonal variability of gasoline-related volatile organic compound emissions in Riverside, California. Environ. Sci. Technol. 2009, 43, 4247-4252. [CrossRef]

11. Gentner, D.; Jathar, S.; Gordon, T.; Bahreini, R.; Day, D.; El Haddad, I.; Hayes, P.; Pieber, S.; Platt, S.; de Gouw, J.; et al. Review of urban secondary organic aerosol formation from gasoline and diesel motor vehicle emissions. Environ. Sci. Technol. 2017, 51, 1074-1093. [CrossRef] [PubMed]

12. Song, C.; Liu, B.; Dai, Q.; Li, H.; Mao, H. Temperature dependence and source apportionment of volatile organic compounds (VOCs) at an urban site on the north China plain. Atmos. Environ. 2019, 207, 167-181. [CrossRef]

13. Zhang, Y.; Wang, X.; Zhang, Z.; Lu, S.; Shao, M.; Lee, F.; Yu, J. Species profiles and normalized reactivity of volatile organic compounds from gasoline evaporation in China. Atmos. Environ. 2013, 79, 110-118. [CrossRef]

14. Yuan, Z.; Lau, A.; Shao, M.; Louie, P.; Liu, S.; Zhu, T. Source analysis of volatile organic compounds by positive matrix factorization in urban and rural environments in Beijing. J. Geophys. Res. Atmos. 2009, 114, D00G15. [CrossRef]

15. Liu, Y.; Wang, H.; Jing, S.; Gao, Y.; Peng, Y.; Lou, S.; Cheng, T.; Tao, S.; Li, L.; Li, J.; et al. Characteristics and sources of volatile organic compounds (VOCs) in Shanghai during summer: Implications of regional transport. Atmos. Environ. 2019, $215,116902$. [CrossRef]

16. Cardelino, C.; Chameides, W. An observation-based model for analyzing ozone precursor relationships in the urban atmosphere. J. Air Waste Manag. Assoc. 1995, 45, 161-180. [CrossRef]

17. Norris, G.; Duvall, R.; Brown, S.; Bai, S. EPA Positive Matrix Factorization (PMF) 5.0 Fundamentals and User Guide; EPA/600/R14/108 (NTIS PB2015-105147); U.S. Environmental Protection Agency: Washington, DC, USA, 2014.

18. Wang, T.; Xue, L.; Brimblecombe, P.; Lam, Y.; Li, L.; Zhang, L. Ozone pollution in China: A review of concentrations, meteorological influences, chemical precursors, and effects. Sci. Total Environ. 2017, 575, 1582-1596. [CrossRef] [PubMed]

19. de Gouw, J.; Middlebrook, A.; Warneke, C.; Goldan, P.; Kuster, W.; Roberts, J.; Fehsenfeld, F.; Worsnop, D.; Canagaratna, M.; Pszenny, A.; et al. Budget of organic carbon in a polluted atmosphere: Results from the New England Air Quality Study in 2002. J. Geophys. Res. Atmos. 2005, 110, D16305. [CrossRef]

20. Song, C.; Liu, Y.; Sun, L.; Zhang, Q.; Mao, H. Emissions of volatile organic compounds (VOCs) from gasoline- and liquified natural gas (LNG)-fueled vehicles in tunnel studies. Atmos. Environ. 2020, 234, 117626. [CrossRef]

21. Mo, Z.; Shao, M.; Lu, S. Compilation of a source profile database for hydrocarbon and OVOC emissions in China. Atmos. Environ. 2016, 143, 209-217. [CrossRef]

22. Cao, X.; Yao, Z.; Shen, X.; Ye, Y.; Jiang, X. On-road emission characteristics of VOCs from light-duty gasoline vehicles in Beijing, China. Atmos. Environ. 2016, 124, 146-155. [CrossRef]

23. Yuan, B.; Shao, M.; Lu, S.; Wang, B. Source profiles of volatile organic compounds associated with solvent use in Beijing, China. Atmos. Environ. 2010, 44, 1919-1926. [CrossRef]

24. Wang, H.; Qiao, Y.; Chen, C.; Lu, J.; Dai, H.; Qiao, L.; Lou, S.; Huang, C.; Li, L.; Jing, S.; et al. Source profiles and chemical reactivity of volatile organic compounds from solvent use in Shanghai, China. Aerosol Air Qual. Res. 2014, 14, 301-310. [CrossRef]

25. Guenther, A.; Karl, T.; Harley, P.; Wiedinmyer, C.; Palmer, P.; Geron, C. Estimates of global terrestrial isoprene emissions using MEGAN (Model of Emissions of Gases and Aerosols from Nature). Atmos. Chem. Phys. 2006, 6, 3181-3210. [CrossRef]

26. Mo, Z.; Shao, M.; Wang, W.; Liu, Y.; Wang, M.; Lu, S. Evaluation of biogenic isoprene emissions and their contribution to ozone formation by ground-based measurements in Beijing, China. Sci. Total Environ. 2018, 627, 1485-1494. [CrossRef] [PubMed]

27. Venecek, M.; Carter, W.; Kleeman, M. Updating the SAPRC maximum incremental reactivity (MIR) scale for the United States from 1988 to 2010. J. Air Waste Manag. Assoc. 2018, 68, 1301-1316. [CrossRef]

28. Huang, Y.; Mok, W.; Yam, Y.; Zhou, J.; Surawski, N.; Organ, B.; Chan, E.; Mofijur, M.; Mahlia, T.; Ong, H. Evaluating in-use vehicle emissions using air quality monitoring stations and on-road remote sensing systems. Sci. Total Environ. 2020, 740, 139868. [CrossRef] [PubMed] 